\title{
A representação de Atores Sociais no discurso da revista Caros Amigos
}

\section{The representation of Social Actors in the discourse of the magazine Caros Amigos}

\author{
Daniele de Oliveira ${ }^{1}$
}

\begin{abstract}
RESUMO: O objetivo deste trabalho é verificar como se estabelece a construção da imagem dos Atores Sociais mídia corporativa, revista Caros Amigos e leitor da mesma no discurso da própria revista. Nosso intuito mais amplo é analisar o discurso veiculado pela denominada mídia alternativa (ou independente), considerando especialmente a construção da opinião expressa. Este trabalho parte dos pressupostos teóricos da Linguística Sistêmico-Funcional de Halliday (1985) e Halliday e Matthiessen (2004), bem como do sistema sociossemântico desenvolvido por Van Leeuwen (2008) a partir da LSF. Para alcançarmos nossos objetivos, analisamos em nossa tese de doutorado a Representação dos Atores Sociais destacados em quinze editoriais e três artigos de opinião da revista Caros Amigos. Neste artigo, apresentaremos um panorama das Representações em todo o corpus, e também a análise específica de dois dos editoriais: "Caminhos" (mar. 2003) e "A linha de frente" (out. 2007). Observamos que uma das estratégias para expressar a opinião nesse discurso é a maneira como é materializada linguisticamente a Representação dos Atores Sociais, especialmente a mídia corporativa, o Ator Social mais frequente em nosso corpus. A mídia corporativa é representada principalmente por Categorizações, ou seja, referida como se se tratasse de uma única instituição homogênea. Além disso, ela é recorrentemente avaliada por meio de Representações que revelam uma crítica que aponta para a falta de ética jornalística.
\end{abstract}

PALAVRAS-CHAVE: Ator social. Mídia alternativa. Representação social.

RESUMEN: El objetivo de este trabajo es verificar cómo se establece la construcción de la imagen de los Actores Sociales: medios corporativos, revista Caros Amigos y lector de la misma en el discurso de la propia revista. Nuestra intención más amplia es analizar el discurso vehiculado por la denominada media alternativa (o independiente), considerando especialmente la construcción de la opinión expresa. Este trabajo parte de los presupuestos teóricos de la Lingüística Sistémico-Funcional de Halliday (1985) y Halliday y Matthiessen (2004), así como del sistema sociosemántico desarrollado por van Leeuwen (2008) a partir de la LSF. Para alcanzar nuestros objetivos, analizamos en nuestra tesis de doctorado la Representación de los Actores Sociales destacados en

\footnotetext{
${ }^{1}$ Doutora em Estudos Linguísticos (Análise Crítica do Discurso e Linguística Sistêmico-Funcional) pela UFMG, contou com bolsa CAPES/REUNI. Mestre em Língua Portuguesa pela PUC/MINAS e graduada em Letras Licenciatura - Português pela UFMG. Foi Coordenadora de Área do PIBID-Letras-Língua Portuguesa da UFBA (2015-2017). Atualmente é Professora Adjunta do Instituto de Letras da UFBA. Linha de pesquisa: Estudos do Texto e do Discurso. Interessa-se, principalmente, por discurso midiático, mídia alternativa, mídia corporativa, gêneros discursivos, ensino de Língua Portuguesa.
} 
quince editoriales y tres artículos de opinión de la revista Caros Amigos. En este artículo, presentaremos un panorama de las representaciones en todo el corpus, y también el análisis específico de dos de los editoriales: "Caminhos" (mar. 2003) y "A linha de frente" (out. 2007). Observamos que una de las estrategias para expresar la opinión en ese discurso es la forma en que se materializa lingüísticamente la Representación de los Actores Sociales, especialmente los medios corporativos, el Actor Social más frecuente en nuestro corpus. Los medios de comunicación corporativa se representan principalmente por Categorizaciones, es decir, se refieren como si se tratase de una única institución homogénea. Además, es recurrentemente evaluada por medio de Representaciones que revelan una crítica que apunta a la falta de ética periodística.

PALABRAS CLAVE: Actor social. Media alternativa. Representación social.

ABSTRACT: This paper intends to verify how the images of the social actors corporate media, magazine Caros Amigos, and the readers of the magazine are constructed in the discourse of the magazine itself. Our intents is to analyze the discourse conveyed in the so called alternative (or independent) media, especially considering the construction of the opinion expressed. This paper follows the Systemic Functional Linguistics by Halliday (1985) and Halliday and Matthiessen (2004), and the Social Semantics System as developed by Van Leeuwen (2008) from the SFL. To reach our goal we have analyzed in our PhD dissertation the representation of Social Actors highlighted in fifteen editorials and three op-eds in Caros Amigos. In this article, we present an overview of the representations in all the corpus, as well as a specific analysis of two of the editorials: "Caminhos" (March 2003) and " $A$ linha de frente" (October 2007). We have noticed that one of the strategies to express opinion in this discourse is the way in which the representation of the social actors is linguistically established, especially the corporate media, the most frequent social actor in our corpus. The corporate media is mainly represented through categorization; it is referred to as if it were one only homogenous institution. Moreover, it is recurrently assessed through representations which reveal criticism against the lack of journalistic ethics.

KEYWORDS: Social actor. Alternative media. Social representation.

\section{Introdução}

A realização desta pesquisa tem sua origem em uma reflexão atenta às questões sociais, aliada ao interesse em voltar um olhar acadêmico para uma delas: a relação que se estabelece entre a mídia e a sociedade por meio do discurso.

A relação entre a mídia e a sociedade sustenta uma associação assimétrica de poder entre aqueles que detêm o espaço para veicular suas ideias, seus posicionamentos, e aqueles que apenas têm acesso a essas 
publicações. Dito de outra forma, entre especialistas, editores de veículos de comunicação e leigos, cidadãos comuns que recebem o conteúdo jornalístico/ideológico diariamente.

O debate sobre a relação entre mídia e a sociedade tem amplo espaço entre pesquisadores tanto da área de linguagem quanto da de comunicação social, bem como de outras áreas correlatas. No entanto, é difícil encontrar pesquisas que tratem especificamente do discurso veiculado nas mídias alternativas. Comumente, a atenção é voltada para o discurso corporativo, ou seja, as grandes empresas de comunicação (revistas Veja, IstoÉ, Época, jornais Folha de S.Paulo, Estado de Minas etc.). Neste trabalho, optamos por investigar o discurso da revista Caros Amigos, considerando-se o fato de ela se autointitular uma revista de esquerda, ou "a primeira à esquerda", como indica o subtítulo na capa da revista. Além disso, trata-se de um veículo que frequentemente reafirma seu aspecto independente. Dessa forma, ela se posiciona à parte da denominada "mídia grande", ou seja, os meios de comunicação de massa, tendo surgido no mercado editorial brasileiro justamente para desafiar e se contrapor ao discurso da mídia corporativa.

A despeito da complexidade do discurso da revista Caros Amigos, neste artigo procuramos investigar a construção identitária dos Atores Sociais mídia corporativa, revista Caros Amigos e leitor da mesma. Nosso objetivo é, pois, observar qual deles é o mais proeminente nesse discurso; que classificações ou categorias são utilizadas para representa-los; se, em geral, recebem papéis ativos ou passivos; se são avaliados positiva ou negativamente. Para tanto, utilizar-nos-emos do aparato teórico metodológico disponibilizado pela Linguística Sistêmico-Funcional (LSF) (HALLIDAY; MATTHIESSEN, 2004) e também do sistema sociossemântico proposto por Van Leeuwen (2008) a partir da própria LSF.

É importante ressaltar que este artigo foi extraído de uma pesquisa mais ampla, desenvolvida em meu doutoramento, na qual o discurso da revista é analisado também em outros aspectos. 


\section{A Linguística Sistêmico-Funcional}

A Linguística Sistêmico-Funcional, doravante LSF, tem sido descrita como uma abordagem semântico-funcional (significado e uso) da língua que demonstra como as pessoas a usam em diferentes contextos, e como ela é estruturada para o uso como um sistema semiótico (EGGINS, 2004). Dessa forma, seus objetivos principais são descrever o sistema da língua, bem como a maneira pela qual esse sistema se relaciona com textos empíricos.

E esses objetivos, por sua vez, podem ser alcançados a partir do avanço das principais afirmações teóricas sobre a língua (EGGINS, 2004, p. 3):

(1) que o uso da língua é funcional;

(2) que sua função é produzir significados;

(3) que esses significados são influenciados pelos contextos social e cultural nos quais eles são trocados;

(4) que o processo de uso da língua é um processo semiótico, um processo de produzir significado pela escolha.

Para Halliday e Matthiessen (2004), a língua é usada para dar sentido a nossa experiência e para interagir com outras pessoas. Sendo assim, a gramática deve se relacionar também com o que ocorre fora da língua: com os acontecimentos e condições do mundo e com os processos sociais nos quais estamos envolvidos. A linguística sistêmica se interessa também por essa relação entre a língua e o contexto (EGGINS, 2004). De alguma forma, 0 contexto está no texto: o texto carrega consigo, como parte dele, aspectos do contexto no qual é produzido e, provavelmente, do contexto no qual pode ser considerado adequado.

Mas, ao mesmo tempo, a gramática deve organizar a interpretação da experiência e o desempenho dos processos sociais, então eles podem ser transformados em texto. $\mathrm{O}$ que pode ser dividido em duas etapas. Na primeira, a interação, a experiência e as relações interpessoais são transformadas em 
significado; esse é o nível da semântica. Na segunda, o significado é, também, transformado em texto; esse é o nível léxico-gramatical (HALLIDAY; MATTHIESSEN, 2004).

A perspectiva sistêmica busca compreender a natureza e a dinâmica do sistema semiótico que a língua constitui como um todo. Dessa forma, a gramática de determinada língua é uma rede de sistemas e não um registro de estruturas. Na visão funcionalista, a estrutura é entendida como parte fundamental da descrição, mas interpretada como a forma exterior assumida pelas escolhas sistêmicas, e não a característica que define a língua. $O$ significado reside, então, nos padrões sistêmicos de escolha (HALLIDAY; MATTHIESSEN, 2004).

A noção de escolha é, pois, central na visão funcionalista da língua. Sendo assim, um texto é o resultado de uma seleção feita pelo falante a partir do potencial de opções disponíveis no sistema linguístico. Ressalte-se o caráter intencional $^{2}$ dessas escolhas, ainda que eventualmente inconscientes, considerando-se que o uso da língua parte sempre de uma razão motivadora (EGGINS, 2004).

Halliday e Matthiessen (2004) propõem que a teoria do registro permite descrever o impacto das dimensões do contexto imediato de situação de um evento de linguagem sobre a maneira como a língua é usada. A LSF identifica três dimensões fundamentais que exercem impacto significativo e previsível no uso da língua. Essas três dimensões, os registros variáveis de modo (organização simbólica da língua), teor (papel das relações pessoais e sociais) e campo (tipo de ação social), são usadas para explicar nossa compreensão intuitiva segundo a qual não utilizamos a língua da mesma maneira para escrever e para falar (variação de modo), para nos dirigirmos a nosso chefe e para falar com nosso namorado (variação de teor) e para discutir linguística e para conversar sobre cinema (variação de campo).

\footnotetext{
${ }^{2}$ Está claro que o caráter intencional dessas escolhas deve ser compreendido tendo-se em vista que elas são influenciadas ideologicamente em função do contexto no qual o falante está inserido.
} 
Além do contexto situacional, descrito pela teoria do registro, o contexto de cultura também deve ser acionado na análise proposta pela LSF. O conceito de gênero ressalta o impacto do contexto de cultura na linguagem, explorando a estrutura institucionalizada como maneira de alcançar objetivos por meio da linguagem (EGGINS, 2004). Se, por um lado, algumas vezes é possível alcançar nossos objetivos por meio apenas de uma pequena troca linguística (como quando perguntamos a hora para um estranho na rua), por outro, a maioria das interações linguísticas requer movimentos linguísticos muito mais complexos.

Eggins (2004) destaca ainda o nível da ideologia como um nível mais alto de contexto ao qual a linguística sistêmica dedica cada vez mais atenção. Qualquer que seja o gênero, qualquer que seja o registro de situação, nosso uso da língua será também influenciado pelos nossos posicionamentos ideológicos: os valores que possuímos (consciente ou inconscientemente) e as perspectivas adquiridas através da nossa trajetória particular no interior da cultura. Dito de outra forma, nossas escolhas linguísticas são fortemente influenciadas por nossas ideologias.

Considerando que a língua tem por objetivo satisfazer as necessidades humanas e, por isso, é organizada de maneira funcional e sistêmica, Halliday e Matthiessen (2004) afirmam que ela é estruturada para produzir três principais tipos de significado simultaneamente. Dessa forma, o sistema semiótico consiste nas metafunções: i) ideacional que constrói a experiência humana, tendo em vista que não há faceta da experiência humana que não possa ser transformada em significado. A metafunção ideacional é subdividida em dois componentes, o experiencial e o lógico; ii) interpessoal, que se refere à linguagem como ação, já que ela ordena nossas relações pessoais e sociais com as outras pessoas; e iii) textual, que permite a construção de sequências de discurso, a organização do fluxo discursivo e a criação da coesão e da continuidade ao longo do texto.

Está claro que as três metafunções não atuam de maneira isolada ou independente na língua, mas interagem entre si com o intuito mais amplo de 
construir o significado do texto. Além disso, as metafunções relacionam-se diretamente com a estrutura léxico-gramatical do texto, 0 que, consequentemente, vai influenciar na estrutura da oração de maneira mais específica. Passemos agora a uma explicação mais detalhada sobre a Metafunção Ideacional com a qual este trabalho se relaciona mais especificamente.

\section{Metafunção Ideacional}

O Sistema de Transitividade proposto por Halliday e Matthiessen (2004) constrói o mundo da experiência a partir de um conjunto de Tipos de Processos. Dessa forma, a Metafunção Ideacional ou Experiencial se relaciona com a realidade presente em determinado texto, ela relaciona o texto e 0 mundo real.

Nossa experiência é construída a partir de uma estrutura bastante simples que consiste de apenas três componentes: a) um processo (grupo verbal); b) os participantes envolvidos no processo (grupos nominais); e $c$ ) as circunstâncias associadas ao processo (sintagmas preposicionados, grupos adverbiais e alguns grupos nominais). O Processo é o elemento central da estrutura e os Participantes estão diretamente envolvidos com ele, sendo que os Participantes variam de acordo com o tipo de Processo presente na oração. $\mathrm{E}$ os componentes Circunstanciais ampliam essa estrutura de alguma forma: temporalmente, espacialmente, causalmente etc. A Circunstâncias não estão diretamente envolvidas com o Processo e seu status na configuração é mais periférico.

Cada tipo de processo, realizado por meio de grupos verbais, possui seu esquema para construir determinado domínio da experiência como uma figura de um tipo específico. Para os autores, os principais tipos de processos de transitividade são o material, o mental e o relacional, mas ressaltam que há outras categorias localizadas nos limites entre eles. No limite entre os processos material e mental está o processo comportamental; no limite entre os processos mental e relacional está o processo verbal; e, por fim, no limite entre os processos relacional e material está o processo existencial. Nenhum processo 
está acima dos demais, por isso eles foram representados por meio de um círculo em Halliday e Matthiessen (2004).

Além dos Processos e Participantes, Halliday e Matthiessen (2004) elencam as Circunstâncias sob as quais os Processos podem acontecer. Para os autores, elas podem ocorrer livremente em todos os tipos de Processos e possuem essencialmente o mesmo sentido em qualquer lugar da oração em que ocorram. Estruturalmente, elas são expressas por grupos adverbiais ou frases preposicionais. A noção de Circunstância parte das noções de quando, onde, como e por quê, ou seja, ela se refere à localização espacial e temporal de um evento, bem como às suas causas. Por fim, as Circunstâncias não têm potencial para se transformarem em Sujeito, ao contrário dos Participantes. Os principais tipos de Circunstâncias são Extensão, Localização, Modo, Causa, Contingência, Acompanhamento, Papel, Assunto e Ângulo. Halliday e Matthiessen (2004) propõem, além dos tipos de Circunstâncias, subcategorias desses tipos.

Neste trabalho, nosso foco é nos Participantes, pois, em geral, é nesse elemento que encontramos os Atores Sociais representados no texto. No entanto, ressalte-se que eles podem ocorrer também nas Circunstâncias.

\section{A representação de Atores Sociais no discurso da revista Caros Amigos}

Em primeiro lugar, faremos um mapeamento da ocorrência dos Atores Sociais: mídia corporativa, revista Caros Amigos e leitor da revista nos textos que compõem o corpus deste trabalho, bem como a função que desempenham em cada oração. Esses são os três Atores Sociais mais frequentemente encontrados no discurso da revista e por isso foram selecionados para nossa análise. Nosso intuito é, pois, verificar como é construída a opinião no discurso da revista por meio de uma análise da representação desses três Atores Sociais, tendo como foco central a mídia corporativa.

É importante ressaltar que este artigo constitui parte de nossa pesquisa de doutorado, portanto, a primeira etapa da análise refere-se a todo o corpus 
da tese, que é composto por quinze editoriais e por três artigos de opinião publicados na revista Caros Amigos. Na segunda etapa, para ilustrarmos as ocorrências, optamos por apresentar exemplos de dois desses textos, dois editoriais, para nos adequarmos ao espaço disponível.

Estamos entendendo o Ator Social na mesma perspectiva adotada por Goffman (2009), a da representação teatral. Sendo assim, todo indivíduo se apresenta, nas mais diversas situações sociais, tentando administrar as impressões que os outros têm dele, da mesma forma que um ator o faz ao representar um personagem diante do público. Van Leeuwen (2008) mostranos um leque de categorias analíticas específicas que estabelecem uma relação entre fenômenos linguísticos e fenômenos sociais e nos permitem fazer inferências sobre como eventos e atores sociais são representados em determinado discurso.

Em nossa análise, consideramos também as equivalências temáticas, já que nosso objetivo é verificar, no discurso da revista Caros Amigos, a importância creditada às categorias léxico-semânticas: mídia corporativa, revista Caros Amigos e leitor desta, bem como sua influência na construção da opinião veiculada nesse discurso. Dessa forma, considera-se mídia corporativa, por exemplo, todas as referências feitas a ela, nas mais variadas formas: direta (a Veja), genérica (a mídia, redes de comunicação), ou por meio de seus representantes (os colegas da profissão). No caso da revista Caros Amigos, consideramos ainda referências metonímicas (esta edição, a legenda) e também jornalistas que compõem a equipe editorial da revista citados nominalmente (Leo Gilson, Marilene Felinto). Por fim, o leitor da revista que também foi identificado como os jovens ou as vanguardas.

A representação dos Atores Sociais em destaque foi analisada adotandose como ferramenta o modelo proposto Van Leeuwen (2008), que, a partir da Metafunção Ideacional, apresenta uma descrição sociossemântica detalhada das maneiras por meio das quais é possível representar um Ator Social em determinado discurso. Esse sistema parte de duas categorias gerais: a exclusão e a inclusão dos atores no discurso. Neste artigo, focaremos os Atores Sociais 
incluídos, tendo em vista nosso objetivo de verificar como é construído o ponto de vista veiculado no discurso da revista Caros Amigos em relação aos Atores Sociais: mídia corporativa, revista Caros Amigos e leitor da revista. Os Atores Sociais são excluídos quando os agentes dos processos descritos não são explicitados e são incluídos quando podem ser personalizados ou impersonalizados, se personalizados, determinados ou indeterminados. Quando determinados, podem ser categorizados quanto à funcionalização ou quanto à identificação. Eles podem ainda ser genericizados ou especificados. Quando especificados, podem ser categorizados por individualização ou por assimilação. Os Atores Sociais podem ser referidos ainda por meio da avaliação. Além desses, o processo de inclusão dos Atores Sociais no discurso pode estar relacionado também à análise de papéis ativos e passivos desempenhados pelos Atores Sociais.

Para alcançarmos nossos objetivos, identificamos, nos quinze editoriais de Caros Amigos selecionados, bem como nos três artigos de opinião que compõem o corpus de nossa pesquisa de doutorado, todas as orações que citavam de alguma forma a mídia corporativa, a revista Caros Amigos e o leitor da revista. Foram encontradas 147 orações nos textos, nas quais localizamos 159 referências à mídia corporativa. A revista Caros Amigos foi citada em 103 orações, sendo 127 ocorrências desse Ator Social. E o leitor da revista foi encontrado em 38 orações, sendo o mesmo número de ocorrências do Ator Social, ou seja, uma ocorrência em cada oração. Essas orações serão analisadas de maneira individualizada, não nos dedicaremos à análise de todo o complexo oracional no qual a oração eventualmente está inserida, tendo em vista que nas orações complexas (EGGINS, 2004) cada oração possui seu Sistema de Transitividade específico.

Como já foi dito, o Sistema de Transitividade proposto por Halliday e Matthiessen (2004) explica a experiência do mundo, sendo que ele parte do Processo (elemento central da estrutura), dos Participantes envolvidos e das Circunstâncias eventualmente associadas ao evento. Dessa forma, a Metafunção Ideacional codifica nossas experiências no mundo e, portanto, será 
útil para a análise da representação dos Atores Sociais mais recorrentemente encontrados no discurso da revista Caros Amigos, considerando-se essa representação um recorte da realidade do mundo à nossa volta.

A mídia corporativa aparece nas orações e complexos oracionais em análise tanto exercendo o papel de Participante quanto no interior de alguma Circunstância. Como Participante, ela exerce dezesseis funções diferentes (Ator, Meta, Beneficiário; Experienciador, Escopo; Comportante, Fenômeno; Dizente, Verbiagem, Alvo; Atributo, Portador, Possuído, Possuidor; Característica, Valor) e como Circunstância aparece em cinco tipos distintos (Circunstâncias de Localização, de Modo, de Causa, de Contingência e de Papel). E, nessa grande diversidade, destacamos a mídia corporativa nas posições de Ator $(36 \%){ }^{3}$ de Meta (13\%), de Dizente (10\%) e de Circunstância de Localização (11\%) como as mais recorrentes. Os $30 \%$ restantes subdividem-se nas outras funções citadas acima.

A primeira observação que se pode fazer é em relação à alta frequência de associação da mídia corporativa aos Processos Materiais, nas posições de Ator e Meta. Os Processos Materiais (HALLIDAY; MATTHIESSEN, 2004) são aqueles que constroem a experiência por meio de uma sequência de mudanças concretas e físicas nas quais o Ator está sempre presente. Dessa forma, há um processo a partir do qual o estado inicial é modificado e tem como resultado um estado final diferente de seu antecessor. Sendo assim, a mídia corporativa, em geral, ocupa a posição de Ator, ou seja, ela age de alguma maneira na maioria das ocorrências. E também é afetada pela ação de outros, já que também aparece com frequência no papel de Meta.

Além dos papéis de Ator e Meta, a mídia corporativa ocupa também com bastante frequência a posição de Circunstância de Localização (11\%) e de Dizente (10\%). Entre as Circunstâncias de Localização nas quais encontramos referências à mídia corporativa, dezoito no total, treze são Circunstâncias de Localização Espacial e quatro são Circunstâncias de Localização Temporal.

\footnotetext{
${ }^{3}$ Os valores percentuais foram arredondados para cima quando a primeira casa decimal após a vírgula era maior ou igual a cinco e para baixo quando menor do que cinco.
} 
Encontramos ainda uma Circunstância que apresenta tanto a Localização Espacial quanto a Temporal.

Podemos destacar ainda as ocorrências nas quais a mídia corporativa exerce a função de Dizente relacionada a Processos Verbais. O Dizente é o responsável pelo Processo Verbal, ou seja, é ele quem diz alguma coisa e sua voz é explicitamente incorporada ao texto. A presença recorrente da voz da mídia corporativa no discurso da revista Caros Amigos revela sua importância nesse discurso e nos ajuda a refletir sobre a opinião construída sobre sua imagem. No entanto, sua voz, na maioria das ocorrências, é citada para ser negativamente criticada, ou seja, o editor da revista ressalta, dessa forma, a diferença entre o seu discurso e o da mídia corporativa.

O Ator Social revista Caros Amigos, como já foi dito, aparece em 103 orações, sendo que encontramos 127 ocorrências desse Ator exercendo fundamentalmente papel de Participante. As funções identificadas foram: Alvo, Ator, Beneficiário, Meta; Experienciador, Fenômeno; Dizente, Verbiagem; Existente; Atributo, Portador; Característica, Valor; Circunstâncias de Localização e de Modo. Nesse caso, os destaques são as funções de Ator (40\% das ocorrências) e de Meta (18\%). Os demais $42 \%$ das ocorrências referem-se à soma das outras funções acima mencionadas. A exemplo do que acontece com a mídia corporativa, a revista Caros Amigos também é representada principalmente nas posições de Ator e Meta, ou seja, a revista também age e é afetada pela ação de outros Atores Sociais na maioria das ocorrências.

Como apontamos anteriormente, o Ator Social, que estamos identificando de maneira genérica como o leitor de Caros Amigos, aparece em 38 orações nos textos em análise. Esse leitor foi encontrado exercendo as seguintes funções: Ator, Beneficiário, Meta; Experienciador; Dizente, Verbiagem; Existente; Portador; Característica. Observe-se que o leitor da revista não apareceu exercendo função de Circunstância em nenhuma oração. As funções mais recorrentes neste caso foram as de Ator, com $46 \%$ das ocorrências, Experienciador, com 13\%, e Portador com 10\%. 
Os três Atores Sociais em destaque ocorrem principalmente ocupando a função de Ator de algum Processo Material, o que demonstra o papel ativo de todos eles dentro do discurso da revista Caros Amigos.

Para a análise fundamentada no modelo de Van Leeuwen (2008) consideramos todas as ocorrências dos Atores Sociais em destaque que se constituem como Grupos Nominais ou Nomes Próprios. Foram, portanto, excluídas as referências anafóricas pronominais e as referências implícitas, por entendermos que elas apenas recuperam sentidos anteriormente construídos exatamente por meio dos Grupos Nominais ou dos Nomes Próprios.

O Ator Social mídia corporativa é representado por meio de Grupo Nominal ou Nome Próprio 124 vezes no corpus selecionado para a tese. As formas pelas quais ela foi representada e suas respectivas proporções são as seguintes: Categorização (67\%), Nomeação (24\%), Especificação (3\%), Identificação (3\%), Impersonalização (2\%) e Generalização (1\%).

A mídia corporativa é representada principalmente por meio da Categorização, ou seja, por identidades e funções que um Ator Social compartilha com outros atores nos processos das interações sociais. Eventualmente a distinção entre Categorização e Nomeação pode ser um tanto obscura, pois Atores Sociais podem ser identificados individualmente (o médico, o pai) ou enquanto grupos (os médicos, os pais). Além disso, a maneira como categorizamos revela nosso ponto de vista em relação ao mundo à nossa volta, ou seja, algumas dessas categorias são histórica e culturalmente variáveis. E outras estão relacionadas ao papel social que se desempenha em determinada situação e podem, portanto, mudar a qualquer momento, como uma profissão.

O leitor de Caros Amigos também é principalmente Categorizado (73\% das ocorrências), considerando-se os Grupos Nominais, já que não foram encontradas ocorrências de Nomes Próprios referentes ao leitor da revista. Ele é classificado justamente por essa identidade de leitor da revista na maioria das ocorrências. Nesse caso, essa condição de leitor da revista também pode mudar a qualquer momento, pois ele pode deixar de ler a revista por qualquer motivo, 
como uma mudança ideológica, por exemplo. Já a revista Caros Amigos é Categorizada em $18 \%$ das ocorrências.

O leitor de Caros Amigos, por sua vez, também aparece de maneira significativa por meio da Assimilação (27\% das ocorrências). A Assimilação pode ser descrita como uma referência não individualizada, mas como grupos, e se realiza pela pluralidade ou mediante um substantivo contável ou que denote um grupo de pessoas.

Os efeitos da alta frequência com que a mídia corporativa é Categorizada em oposição à recorrência de nomeação da própria Caros Amigos revelam intenções implícitas no discurso da revista. De fato, já que a primeira é classificada como uma instituição única e homogênea cuja função é comunicar, não é possível identificar, no discurso de Caros Amigos, as particularidades de cada um dos meios de comunicação que juntos compõem a instituição denominada mídia corporativa. Já a identidade de Caros Amigos é reafirmada a todo momento, como veremos na análise da próxima categoria.

A Nomeação da mídia corporativa também acontece em número que é importante registrar, $24 \%$ das ocorrências. Nomear um Ator Social é representálo por sua identidade única, ou seja, por seu nome próprio, o que pode ser considerado uma estratégia ideológica poderosa, considerando-se que por meio da Nomeação é possível inferir os diferentes modos pelos quais percebemos e diferenciamos os diversos Atores Sociais. E aqui é possível apontar uma diferença entre a Nomeação da mídia corporativa (24\%) e a da própria Caros Amigos, que acontece em 39\% das ocorrências.

A frequente Nomeação da revista Caros Amigos pode indicar uma tentativa de a revista se autoafirmar ideologicamente entre seus leitores, ao passo que a mídia corporativa, em geral, não é Nomeada, mas principalmente Categorizada, provavelmente com o intuito de se criar uma ideia de que todas as outras mídias são iguais ou compactuam os mesmos princípios ideológicos. Dessa forma, o discurso veiculado em Caros Amigos cria uma falsa impressão de homogeneidade em relação ao que denomina "mídia grande". O que confirma a tendência observada quando apontamos a recorrente Categorização 
dos veículos de comunicação, como se constituíssem uma única instituição homogênea.

A revista Caros Amigos emerge em seu próprio discurso também de maneira Impessoal, em 39\% das ocorrências, ou seja, nesses casos ela é representada por substantivos que não incluem o traço semântico "humano".

De acordo com Van Leeuwen (2008), as representações discursivas podem dotar os Atores Sociais com papéis Ativos ou Passivos em determinado discurso. O Ator Social é Ativo quando possui forças dinâmicas em uma atividade, quando desencadeia a ação representada no processo; e Passivo quando sofre a ação da atividade, ou quando é o recebedor final dela.

A Ativação ou Passivação de um ator social será realizada por meio dos papéis gramaticais que desempenha em um discurso (HALLIDAY, 1985). Dessa forma, o Ator Social será Ativo quando exercer a função de Ator em Processos Materiais, de Comportante em Processos Comportamentais, de Experienciador em Processos Mentais, de Dizente em Processos Verbais ou de Portador em Processos Relacionais. E será Passivo quando exercer a função de Meta ou de Beneficiário em Processos Materiais, Fenômeno em Processos Mentais, Receptor em Processos Verbais ou ainda por meio da circunstancialização ou da possessivação do participante.

A mídia corporativa ocupa principalmente função Ativa, $48 \%$ das ocorrências de representação por meio de Grupos Nominais ou Nomes Próprios, e em posição Passiva ela aparece em $37 \%$ delas. Aqui estamos excluindo as ocorrências nas quais a mídia corporativa aparece em outras funções diferentes das mencionadas no parágrafo anterior, tais como Valor, Característica, Atributo, que somadas representam $15 \%$ das ocorrências.

O significado de "ativar" ou "passivar" um Ator Social em determinado discurso é muito transparente. Quando o Ator Social é principalmente Ativo, sua capacidade de agir, de fazer as coisas acontecerem, é acentuada, quando ele é principalmente Passivo o que está em destaque é sua sujeição aos processos, o Ator Social é afetado pela ação de outros. No caso da mídia corporativa no discurso de Caros Amigos, o que está em destaque é sua capacidade de ação, 
haja vista sua ocorrência predominante de forma Ativa, principalmente como Ator em Processos Materiais. Entre as ocorrências da mídia corporativa nas quais ela aparece de modo Ativo, ela exerce a função de Ator em mais da metade dos casos.

O leitor de Caros Amigos também é principalmente Ativo no discurso da revista, já que aparece em posição Ativa em $68 \%$ das ocorrências encontradas.

Ao contrário dos atores mídia corporativa e leitor de Caros Amigos, a própria revista recebe, em geral, um papel Passivo (52\% das ocorrências). No entanto, ela aparece em seu próprio discurso com papel ativo em $40 \%$ das ocorrências, ou seja, no caso desse Ator Social há um equilíbrio maior, se comparado com os demais atores analisados.

Passemos agora à ilustração de algumas das categorias apontadas acima por meio da análise dos editoriais "Caminhos" (mar. 2003) e "A linha de frente" (out. 2007). Selecionamos esses editoriais por entendermos que eles constituem exemplares representativos do aspecto discursivo que vamos analisar, a representação de Atores Sociais, uma vez que apresentam diversos exemplos dos atores selecionados e que, portanto, refletem o que observamos em nossa pesquisa de doutorado em relação ao discurso da revista considerado de maneira mais ampla.

\section{Editorial "Caminhos"}

O editorial "Caminhos" (mar. 2003) trata da estreia da jornalista Marilene Felinto nas páginas de Caros Amigos logo depois de ter sido repentinamente demitida da Folha de S.Paulo. Nesse texto, o editor reflete ainda sobre a questão da ética no jornalismo e da necessidade de o jornalista se manter independente, ainda que isso lhe custe o emprego, como foi o caso de Marilene Felinto. Vejamos o texto completo:

1. Marilene Felinto estreia, com a seção que ela própria batizou: Desaviso. 
2. Significativo substantivo para uma jornalista substantiva.

3. Assim que se tornou pública sua demissão da Folha de S.Paulo, onde há anos assinava uma coluna semanal, começaram a chegar à nossa redação manifestações de leitores protestando contra o jornalão e sugerindo que ela passasse a escrever em Caros Amigos.

4. Ao mesmo tempo, Marilene recebia carradas de cartas de solidariedade e estranheza pela forma como a Folha anunciou a violência (uma lacônica, porque envergonhada, nota de redação).

5. Assim, viu-se, mais uma vez, que não passam de meras lorotas esses slogans que falam em independência, imparcialidade e outros atributos nobres alardeados pelos jornalóes.

6. O da familia Frias não foge à regra nacional, rabo preso sim, mas não com o leitor, como ficou claro no episódio.

7. Na verdade, está cada vez mais difícil esconder onde está preso 0 rabo da mídia grande no Brasil, porque há um público cada vez maior recebendo cada vez mais informações, principalmente via Internet.

8. Vem vindo aí uma geração indigesta para os que pretendem mascarar seus reais propósitos e compromissos.

9. Editoriais sorrateiros, reportagens dirigidas, entrevistas distorcidas, a mão pesada dos proprietários dos veículos pairando sobre a cabeça das redações.

10. Impossível um jornalista crítico do establishment sobreviver num meio tão controlado.

11. Há exceções, claro, e Marilene é uma delas.

12. Que frutifique o seu exemplo, que pelo menos os mais jovens, esses que saem anualmente aos borbotões das faculdades de comunicação (outro abacaxi a descascar), tomem ciência de que a ética na profissão - qualquer profissão - deve ser o corriqueiro, não o extraordinário.

13. E que a independência é vital, ainda que à custa do emprego.

14. Bem-vinda, Marilene Felinto! 
As orações acima, (1) a (14), contêm várias representações dos Atores Sociais que destacamos em nosso trabalho. Vejamos cada uma delas.

Nesse texto, o Ator Social mídia corporativa é representado de forma Ativa em (4) a Folha [Ator] anunciou a violência, (5) alardeados pelos jornalões [Ator], (6) O da familia Frias [Ator] não foge à regra nacional, (7) onde está preso o rabo da mídia grande [Portador] e (9) Editoriais sorrateiros, reportagens dirigidas, entrevistas distorcidas, a mão pesada dos proprietários dos veículos [Ator] pairando sobre a cabeça das redações. E de forma Passiva em (3) protestando contra o jornalão [Meta] e (10) Impossível um jornalista crítico do establishment sobreviver num meio tão controlado [Circunstância de Localização].

Além disso, a mídia corporativa é Categorizada em (3) o jornalão, (5) jornalões, (7) mídia grande e (9) proprietários dos veículos, Nomeada em (3) Folha de S.Paulo e (4) a Folha; Identificada em (6) o da familia Frias e (10) meio tão controlado; por fim, é Impersonalizada em (9) editoriais sorrateiros, reportagens dirigidas, entrevistas distorcidas.

Nos exemplos (7), (9) e (10) foram agregadas outras informações além da Categorização, Impersonalização e Identificação, respectivamente: (7) mídia grande; (9) editoriais sorrateiros, reportagens dirigidas, entrevistas distorcidas, e (10) meio tão controlado. Essas informações podem ser consideradas avaliações feitas pelo autor do texto sobre o Ator Social.

Passando para a análise das ocorrências do Ator Social revista Caros Amigos em seu próprio discurso, observamos que ela é Ativada em (1) Marilene Felinto [Ator] estreia, e em (4) Marilene [Ator] recebia carradas de cartas de solidariedade e estranheza. E referida de forma Passiva em (3) começaram a chegar à nossa redação [Meta] manifestações de leitores protestando contra o jornalão e sugerindo que ela passasse a escrever em Caros Amigos [Circunstância de Localização].

A revista Caros Amigos, nesse texto, é principalmente referida por meio da Nomeação: (1) Marilene Felinto, (3) Caros Amigos, (4) Marilene, (11) Marilene e (14) Marilene Felinto. Ressaltamos aqui nossa opção por considerar 
as referências a jornalistas da Caros Amigos como referências à própria revista, tendo em vista que se trata de referências metonímicas. Encontramos ainda uma Categorização (2) jornalista substantiva e uma Impersonalização (3) nossa redação. No caso da revista Caros Amigos, mais especificamente da jornalista Marilene Felinto, identificamos uma Avaliação que se refere a um aspecto positivo da profissional em (2) uma jornalista substantiva e, por extensão, da própria revista.

Por fim, citemos a única referência ao leitor da revista em (3) de leitores [Ator] protestando contra o jornalão. Trata-se de uma forma Ativa e de uma Categorização desse Ator Social.

No exemplo (6), há uma referência ao leitor que não consideramos em nossa análise por se tratar especificamente do leitor da Folha de São Paulo. 0 Ator Social que selecionamos para análise foi o leitor específico da revista Caros Amigos, que em geral é identificado por meio de sua participação na revista com cartas ou e-mails, além da mídia corporativa e da própria Caros Amigos.

Voltando nossa atenção para as representações do Ator Social mídia corporativa nesse editorial, especialmente o uso de Grupos Nominais, observamos o caráter irônico da maioria delas: (3) jornalão, (5) jornalões, (6) 0 da família Frias e (7) o rabo da mídia grande. A ironia pode ser entendida como uma contradição argumentativa (BERRENDONNER, 1987), tendo-se em vista que a ideia de contrário deve ser entendida como valor argumentativo inverso, e não, simplesmente, antônimo. Dessa forma, a ironia é resultado da tensão entre os sentidos literal e derivado de determinado enunciado.

Em (3) e (5), o uso do aumentativo pode ser entendido como uma ironia porque reflete a dicotomia insistentemente repetida no discurso da revista Caros Amigos que relaciona a mídia grande a um jornalismo de pouca qualidade, sem ética. Nesses casos, (3) e (5), o aumentativo não revela apenas o tamanho físico (ou alcance) do jornal, mas um aspecto negativo de sua prática jornalística ironizada a partir de uma ação concreta, qual seja, a demissão repentina da jornalista Marilene Felinto. 
Em (6), o editor de Caros Amigos ressalta o aspecto corporativo da Folha, entendida como uma empresa com fins lucrativos e comandada por uma família. A ironia está justamente nesse comando corporativo que resulta, segundo o autor do texto, em um rabo preso, ainda que ele não tenha especificado com quem. Esse sentido irônico se completa com (7), onde o rabo da mídia grande é referido de maneira a levar o leitor a estabelecer uma relação entre a Folha e algum animal que tenha rabo. Ora, associar a Folha a um animal, um ser não racional, revela um sentido não materializado textualmente, mas que pode ser inferido. Dessa forma, a intenção do autor do texto permite inferir que, segundo o editor de Caros Amigos, a equipe da Folha age sem pensar, de modo irracional, ou ainda, tem atitudes não esperadas ou não coerentes com um veículo desse porte.

Além da ironia, observamos também as avaliações presentes nos Grupos Nominais presentes em (9) e (10) que revelam o ponto de vista do editor da revista em relação à mídia corporativa, construindo, dessa forma, uma imagem negativa da mesma. Em (9), ele destaca o aspecto dissimulado da Folha ao se referir a editoriais sorrateiros, o que demonstraria também suas intenções obscuras. $\mathrm{O}$ que é reforçado pela qualificação das reportagens e das entrevistas publicadas pela Folha que seriam, respectivamente, dirigidas e distorcidas.

Considerando-se que a ética é um dos fundamentos do trabalho jornalístico (na verdade, de qualquer trabalho), fica patente a intenção do editor de Caros Amigos em construir uma imagem fortemente negativa da mídia corporativa em seu discurso, aqui exemplificado pelo editorial "Caminhos". Partindo de uma ação da Folha, a demissão sumária de uma jornalista, ele ironiza a representação desse jornal e, por extensão, de toda a mídia corporativa brasileira. Observe-se também que, no discurso de Caros Amigos, a mídia corporativa, em geral, é retratada como uma instituição única, embora se refira a diversos meios de comunicação, tais como revistas Veja e IstoÉ, jornais Folha e Estado de São Paulo, organizações Globo, para mencionarmos apenas aqueles que encontramos citados nominalmente em nosso corpus completo. Nos enunciados (7), (9) e (10) identificamos 
referências à Folha, mas que também podem estar relacionadas à mídia corporativa em geral: (7) o rabo da mídia grande, (9) editoriais sorrateiros, reportagens dirigidas, entrevistas distorcidas, a mão pesada dos proprietários dos veículos e (10) meio tão controlado.

Pode-se dizer, então, que a representação da mídia corporativa no editorial "Caminhos" contribui para a construção de uma imagem fortemente negativa da mesma. De fato, ironizar o trabalho da Folha, que pode ser entendida como uma representação metonímica da mídia corporativa como um todo, funciona nesse discurso como uma estratégia discursiva cuja intenção é ressaltar seus aspectos negativos.

Em contrapartida ao que foi dito sobre a representação da mídia corporativa, observamos que a própria Caros Amigos, em geral representada pela Nomeação (1), (4), (11) e (14), tem seus aspectos positivos realçados já que recebe a jornalista demitida da Folha. Ressalte-se que a revista é representada também metonimicamente quando é referida por meio de uma de suas jornalistas. Com a Nomeação a identidade da revista é reafirmada em contraposição à maior frequência de Categorizações da mídia corporativa.

Além disso, a Avaliação presente em (2) mostra o ponto de vista do editor de Caros Amigos em relação à nova jornalista: substantiva. Esse termo remete à substância, ou seja, pode-se dizer que o autor do texto considera Marilene Felinto uma profissional de conteúdo, que produz textos com conteúdo, ao contrário do que pratica a mídia corporativa, tanto que ela foi violentamente demitida da Folha. Dessa forma, ele ressalta a contraposição entre o jornalismo praticado pela revista e o praticado pela mídia corporativa.

A contraposição dos dois tipos de jornalismo, nesse editorial, é construída a partir de um fato que, segundo o editor de Caros Amigos, demonstraria a falta de ética da Folha. Pode-se dizer, então, que por meio da representação desse Ator Social foi possível apreender o ponto de vista do autor do texto em relação a ele, a avaliação desse Ator Social. Dessa forma, ressaltamos o aspecto avaliativo que as representações de atores sociais podem assumir em determinado discurso. 


\section{Editorial "A linha de frente"}

O editorial "A linha de frente" (out. 2007) trata do $1^{\circ}$ Anticurso de Jornalismo Caros Amigos. 0 editor fala como foi o curso, sobre os participantes, passa por uma crítica aos jornalistas que, segundo ele, não são éticos e fecha retomando os ideais da Revolução Francesa: igualdade, liberdade e fraternidade. Vejamos o editorial na íntegra:

15. Talvez boa parte dos leitores não tenha tomado conhecimento do $1^{0}$ Anticurso de Jornalismo Caros Amigos, que seria encerrado no primeiro sábado de outubro (o verbo está no condicional porque o encerramento se daria depois de esta edição estar fechada).

16. Em princípio, a idéia do Anticurso causou estranheza a umas pessoas, mas não aos 63 jovens que se inscreveram, entre eles sete de Curitiba (que cada vez vieram e voltaram de ônibus), um de Caxias do Sul (também de ônibus) e um do Rio Grande do Norte (que, hospedado em casa de parentes, passou o mês todo em São Paulo e em nossa redação).

17. Havia ainda onze inscritos vindos do Rio de Janeiro, Itatiba, Campinas, Jundiaí, Sorocaba, Ribeirão Preto e São José do Rio Preto. A maioria - 60 por cento - moças.

18. Foram, se tudo correu direito no encerramento, oito palestras, duas por sábado, por conta de José Arbex Jr., Mylton Severiano, Marcos Zibordi, Cláudio Tognolli, Georges Bourdoukan, Renato Pompeu, Verena Glass e Claudius.

19. Em lugar de deitar regras, a proposta era cada palestrante expor seus conceitos a respeito da profissão, contar suas experiências e responder a perguntas dos antialunos, se podemos chamá-los assim.

20. Até aqui tudo deu certo, tanto que já estamos estruturando o $2^{\circ}$ Anticurso.

21. Os jovens que se inscreveram nesse primeiro decerto concordam com o subtítulo da proposta: "Como não enriquecer na profissão". 
22. O que significaria, principalmente, que acreditam na independência pessoal, isto é, não desejariam fazer carreira à custa de sacrificar as próprias ideias e ideais em benefício das ideias e ideais dos donos das empresas de comunicação.

23. Pois é dessa forma, enfiando a consciência na terra, que os jornalistas avestruzes acabam amealhando pequenas riquezas que Ihes propiciam frequentar os meios dos abastados, dos patrões e amigos dos patrões, longe o quanto possível da maioria da população, essa mesma cujos direitos mínimos eles fingem defender em seus escritos.

24. A tragicomédia burguesa de sempre, que nunca deveríamos esperar de supostos formadores de opinião.

25. Felizmente, sempre existirão também as vanguardas que batalharão contra a mediocrização da sociedade proposta pelos jornalões $e$ revistas das empresas grandes de comunicação.

26. Para essas vanguardas é dirigida a ideia do Anticurso, e a resposta ao $1^{\circ}$ foi sintomática: elas são a minoria que, na profissão, tratará de promover o conhecimento mais amplo possível das injustiças sofridas pela maioria.

27. É a guerra desigual pela igualdade, liberdade e fraternidade, principalmente esta última, cada vez mais inalcançável no atual mundo de caixa dois.

28. Mais uma estreia auspiciosa: Joel Rufino dos Santos, carioca, autor de mais de 30 livros e da História Nova do Brasil, coleção didática que lhe custou uma prisão nos anos da ditadura militar.

29. Ele assinará a seção de livros.

Nesse texto, o Ator Social mídia corporativa é representado de forma Ativa em (23) que os jornalistas avestruzes [Ator] acabam amealhando pequenas riquezas, e em (25) proposta pelos jornalões e revistas das empresas grandes de comunicação [Ator]. E de forma Passiva em (22) à custa de sacrificar as próprias ideias e ideais em benefício das ideias e ideais dos donos das empresas de comunicação [Meta] e em (24) que nunca deveríamos esperar de supostos formadores de opinião [Meta]. Todos os exemplos citados constituem formas de Categorização do Ator Social mídia corporativa: (22) 
donos das empresas de comunicação, (23) jornalistas, (24) formadores de opinião e (25) jornalões e revistas.

Os exemplos (23), (24) e (25) contêm ainda outras informações adicionadas à Categorização que, como vimos, podem ser consideradas formas de Avaliação do Ator Social em questão. Em (23) jornalistas avestruzes, em (24) supostos formadores de opinião e em (25) jornalões e revistas das empresas grandes de comunicação. Dessa forma, os adjetivos supostos e grandes, e os substantivos avestruzes e jornalões constituem avaliações negativas em relação à mídia corporativa de acordo com o ponto de vista do editor de Caros Amigos.

De fato, as representações por meio de Grupos Nominais podem, em muitos casos, revelar avaliações relativas aos Atores Sociais aos quais estão associadas. Em sentido figurado, o termo avestruz pode se referir a indivíduo de má reputação, a pessoa ignorante e pode indicar também covardia, de acordo com do Dicionário Houaiss da Língua Portuguesa. Essas não são as qualidades esperadas de um jornalista. Na verdade, essas qualidades tornam os profissionais da mídia corporativa jornalistas covardes e de má reputação no discurso de Caros Amigos. Tal avaliação permite ainda questionar seu profissionalismo em (24) supostos formadores de opinião, já que por não preencherem os requisitos que os qualificariam como jornalistas, não seriam, portanto, merecedores desse título.

Mais uma vez, o editor da revista se refere à falta de ética dos jornalistas que atuam na mídia corporativa, o que demonstra sua avaliação em relação a esse Ator Social. Para ele, esses jornalistas não trabalham de forma transparente, defendendo os interesses da maioria da população, ao contrário, procuram se aproximar exatamente da minoria abastada.

Em (25) mais uma vez é feita uma referência ao tamanho/alcance da mídia corporativa. Ressalte-se ainda o termo empresa nessa representação. Ele é recorrentemente utilizado no discurso da revista para reforçar a ideia de que a mídia corporativa tem por objetivo apenas o lucro, como em qualquer outra empresa, e não a transmissão de informação clara e isenta de 
comprometimentos. Esse pressuposto explicaria a presença de (23) jornalistas avestruzes em seu corpo editorial, além de novamente se referir à questão da (ausência de) ética profissional desses jornalistas.

O Ator Social revista Caros Amigos emerge nesse texto de forma Ativa em (15) depois de esta edição [Ator] estar fechada, em (16) a ideia do Anticurso [Ator] causou estranheza a umas pessoas, e em (26) Para essas vanguardas é dirigida a ideia do Anticurso [Ator], e a resposta ao $1^{0}$ [Ator] foi sintomática. E de forma Passiva em (15) Talvez boa parte dos leitores não tenha tomado conhecimento do $1^{0}$ Anticurso de Jornalismo Caros Amigos [Fenômeno], em (16) passou o mês todo em São Paulo e em nossa redação [Circunstância de Localização], em (20) tanto que já estamos estruturando $02^{\circ}$ Anticurso [Meta] e em (29) Ele assinará a seção de livros [Meta].

Nesse editorial, a revista Caros Amigos é principalmente Nomeada, como em (15) $1^{\circ}$ Anticurso de Jornalismo Caros Amigos, (20) $2^{\circ}$ Anticurso e (28) Joel Rufino dos Santos, mas aparece também de forma Impersonalizada em (15) esta edição, (16) nossa redação e em (29) seção de livros.

Entre as representações da revista Caros Amigos, podemos destacar as que se referem ao Anticurso de Jornalismo proposto: (15), (16), (20) e (26), que funcionam como avaliações do curso. O prefixo anti- remete a um posicionamento contrário a ou em oposição a, além de potencializar essa noção de oposição ou contrariedade. Sendo assim, mais uma vez o editor de Caros Amigos ressalta a diferença entre 0 jornalismo praticado pela revista e 0 jornalismo praticado pela mídia corporativa. Nesses casos, o uso do prefixo anti- em anticurso torna patente a oposição referida.

No que se refere ao Ator Social leitor da revista, ele é citado de modo Ativo em (15) Talvez boa parte dos leitores [Experienciador] não tenha tomado conhecimento do $1^{\circ}$ Anticurso de Jornalismo Caros Amigos, (16) mas não aos 63 jovens [Ator] que se inscreveram e em (21) Os jovens [Ator] que se inscreveram nesse primeiro. E de modo Passivo em (19) e responder a perguntas dos antialunos [Receptor] e em (26) Para essas vanguardas [Meta] é dirigida a ideia do Anticurso. O leitor da revista é fundamentalmente 
Categorizado nesse editorial como em (15) leitores, (17) onze inscritos, (19) antialunos e (25) as vanguardas.

Pode-se ressaltar o caráter Avaliativo dos próprios substantivos utilizados para referir ao leitor: antialunos e vanguardas nos exemplos (19) e (26), respectivamente. Ressalte-se a presença de uma oração modalizadora, se podemos chama-los assim, que se refere à representação antialunos em (19), o que pode indicar um não comprometimento total com o termo escolhido.

Mais uma vez utiliza-se o prefixo anti-, nesse caso para demonstrar a conexão entre o jornalismo de Caros Amigos, ensinado por meio de um anticurso, e o seu leitor, aqui representado pelos antialunos. A adesão desses antialunos ao curso os torna vanguardas, no que se refere à prática jornalística, ou seja, eles estariam à frente dos jornalistas da mídia corporativa tão veementemente criticada no discurso de Caros Amigos. Nesse caso, infere-se que a conotação desses termos é positiva, nesse contexto que exalta a opção desses jovens por fazer um jornalismo diferente do praticado pela mídia corporativa e mais de acordo com o praticado por Caros Amigos.

\section{Considerações finais}

Diante do exposto, observamos que a representação de atores sociais revela muito da opinião da revista. Nesse discurso, as formas de representação emergem também como avaliações desses atores. E nessas avaliações podemos destacar a questão da (ausência de) ética jornalística como fundamento para críticas especialmente negativas em relação à mídia corporativa. Ressalte-se que a mídia corporativa é principalmente Categorizada, ou seja, referida como se se tratasse de uma única instituição homogênea. Ainda que tenhamos identificado algumas representações específicas da Folha de São Paulo, pode-se dizer que as avaliações, em geral, são extensivas a toda a mídia corporativa brasileira.

A análise da construção de identidades sociais em determinado discurso permite compreender seu importante papel na formação da opinião pública. 
Dessa forma, as representações de atores sociais constituem importantes recursos argumentativos nesse discurso. Nossa análise buscou, pois, evidenciar as formas por meio das quais o aspecto ideológico do texto opinativo se evidencia discursivamente, a partir de um recurso textual. Por fim, ressaltamos a importância de o leitor ter consciência dessas estratégias para que suas leituras sejam verdadeiramente críticas e jamais passivas.

\section{Referências}

BERRENDONNER, Alain. Elementos de pragmatica linguística. Buenos Aires: Gedisa, 1987.

EGGINS, Suzanne. An introduction to systemic functional linguistics. London: Continuum, 2004.

GOFFMAN, Erving. A representação do eu na vida cotidiana. 16. ed. Petrópolis: Vozes, 2009.

HALLIDAY, Michael Alexander Kirkwood. An introduction to functional grammar. London: Edward Arnold, 1985.

HALLIDAY, Michael Alexander Kirkwood; MATTHIESSEN, Christian Mathias Ingemar Martin. An introduction to functional grammar. London: Hodder Education, 2004.

VAN LEEUWEN, Theo. Discourse and practice. New tools for critical discourse analysis. Oxford: University Press, 2008. 